\title{
Bertrand Russell, The Utilitarian Pacifist
}

Bertrand Russell, Pacifiste utilitariste

\section{Olivier Esteves}

\section{OpenEdition}

\section{Journals}

Electronic version

URL: http://journals.openedition.org/rfcb/308

DOI: $10.4000 / \mathrm{rfcb} .308$

ISSN: 2429-4373

\section{Publisher}

CRECIB - Centre de recherche et d'études en civilisation britannique

\section{Printed version}

Date of publication: 15 January 2015

ISSN: 0248-9015

\section{Electronic reference}

Olivier Esteves, «Bertrand Russell, The Utilitarian Pacifist », Revue Française de Civilisation Britannique [Online], XX-1 | 2015, Online since 01 May 2015, connection on 19 April 2019. URL : http:// journals.openedition.org/rfcb/308; DOI : 10.4000/rfcb.308

This text was automatically generated on 19 April 2019

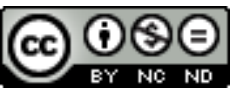

Revue française de civilisation britannique est mis à disposition selon les termes de la licence Creative Commons Attribution - Pas d'Utilisation Commerciale - Pas de Modification 4.0 International. 


\title{
Bertrand Russell, The Utilitarian Pacifist
}

\author{
Bertrand Russell, Pacifiste utilitariste
}

Olivier Esteves

1 Having emerged from a decade in his Cambridge Ivory Tower to write a three-volume essay which would change mathematics, ${ }^{1}$ Bertrand Russell became almost overnight a worshipped or hated public speaker, organiser of public meetings, editorialist for socialist and / or pacifist papers such as The Labour Leader or The Tribunal, negotiator with ministers to guarantee the exemption of conscientious objectors, and also a man who pleaded with Asquith, Lloyd George and Woodrow Wilson. All of this would cost him not only his job at Trinity College Cambridge but also much of his freedom of movement, ${ }^{2}$ would prevent him from going to Harvard, and then send him to Brixton prison to think twice about having become "one of the most mischievous cranks in this country", ${ }^{3}$ to quote Lord Newton's moving encomium. As it would be unrealistic to try to give here a thorough account of Russell's political evolution in these pivotal years, I have decided instead to focus primarily on the complexity of his pacifist stance, partly dependent on the many changes in the war, whether at home or abroad. The reason for this focus on pacifism is that it seems to me that this household name in the British intellectual ${ }^{4}$ canon is too often limited to a few comfortable stereotypes, which contribute to making him a one-dimensional, innocuous sage, almost like some British Dalai Lama enjoying cosy chats on $\mathrm{BBC}$, during the many years when he was very old. This originally half-baked notion was confirmed to me by a few discussions with members of the Russell Peace Foundation, notably Tony Simpson, at a time when the project to translate Russell's Great War texts into French started to painfully materialize. ${ }^{5}$

2 The crucial First World War period, when he was already in his forties, suggests that he was both an indefatigable campaigner for peace and a man with a very ambivalent opinion on pacifism itself. For herein lies a paradox : the very man who took so many risks to promote peace cannot be placed alongside other great peace champions, like Gandhi, Tolstoy, or G. M. Trevelyan. To investigate this paradox involves looking into the various categories of war elaborated by Russell, which delineate a consequentialist 
attitude towards war, and even towards pacifism. This is how one can make sense of his at first very enthusiastic and then lukewarm support for the No-Conscription Fellowship (N.C.F). Lastly, the reason he was to take some critical distance from a group of radical people (led by figures he nevertheless saw as heroes), has to do with his specific viewpoint on matters which became more pressing as the war developed, i. e. the link between pacifism, violence and revolution.

\section{Justified wars}

\section{The four categories of war}

3 In an article entitled "The Ethics of War" (January 1915) which he contributed to The International Journal of Ethics, the British philosopher tries to answer the ethical question: which wars, if any, can be justified? Aware that there is always a degree of simplification involved in such a job, Russell nevertheless ventures a distinction between four types of war : 1 / Wars of colonization ; 2/ Wars of principle ; 3 / Wars of self-defence ; 4/ Wars of prestige. He argues that the first two may be justified, the third seldom so, "except as against an adversary of inferior civilization", ${ }^{6}$ whereas the fourth, to which the current conflict belonged, was absolutely never acceptable. The points he makes about the legitimacy of wars of colonization are interesting in that they evince a sense of ethnocentric ${ }^{7}$ pride rooted in a liberal ideal of (Western) civilization which he would more and more dismiss as jingoistic humbug as the war dragged on.

He starts off by saying that such wars of colonization often belong to the past. Then, at this fairly early stage of World War I, he admits that it is hard "to condemn the process by which the American continent has been acquired for European civilization". ${ }^{8} \mathrm{He}$ goes on to state that "in order that such wars may be justified, it is necessary that there should be a very great and undeniable difference between the civilization of the colonizers and that of the dispossessed natives $" .9$ Countless times during the First World War, Russell warned that the conflict would tragically "lower the standards" of civilisation, which might precipitate the downfall of Europe just like Rome itself had fallen..$^{10}$ By 1919, in "Socialism and Liberal Ideals", he would both dismiss "the exploitation of inferior races" as the "tyrannical phase" of "capitalism ", and "modern imperialism" as the "tyrannical phase" of "nationalism", ${ }^{11}$ ideas that he had toyed with in 1916 and 1917, for example in his series of talks "The World as it can be made". ${ }^{12}$

"Wars of principle" may sometimes be justified. These too often belong to the past, and Russell illustrates this with the example of the Protestant / Catholic wars, and the American or English civil wars. In these, one side at least is "honestly convinced that the progress of mankind depends upon the adoption of certain beliefs or institutions"13 and is ready to wage war for it. These noble ideals notwithstanding, such wars are often counterproductive and are generally legitimated on flimsy grounds.

Wars of "self-defence" are almost universally acknowledged as legitimate, and are " condemned only by Christ and Tolstoy". Nevertheless, self-defence is very often brandished as an excuse by war-mongers : "the justification of wars of self-defence is very convenient, since so far as I know there has never yet been a war which was not one of self-defence". ${ }^{14}$ Russell goes on to deconstruct the claims of legitimacy by each belligerent nation, wherein it becomes obvious that self-defence is confused with an alleged threat of aggression, or the threat to one nation's supremacy in one or another respect (such as control of the seas for Britain). 
7 Lastly, "wars of prestige" are dismissed as unjustifiable : the ongoing war, which was primarily about the "hegemony of the Balkans [...] is entirely a question of prestige". Russell associates such conflicts with the nations' desire for triumph, and the fear of humiliation at the hands of our enemies. He then expresses the hope that, much like individuals in Anglo-Saxon countries have abandoned the practise of duelling and dismissed it as a "folly and delusion", the honour of nations will not "be measured by their willingness to inflict slaughter". ${ }^{15}$ In more metaphorical terms, he declares, in "War and Non-Resistance" (August 1915, The Atlantic Monthly), that "we should have put Shakespeare on the Nelson Monument, and given Apsley House to Darwin. But the citizens that every nation honours most are those who have killed the greatest number of foreigners". ${ }^{16}$ National honour is not negative per $s e:$ it is to be sought for in artistic or scientific terms (corresponding to what he calls "creative impulses" in Principles of Social Reconstruction) whereas it is to be dismissed as destructive in military or imperialistic fields (corresponding to what he calls "possessive impulses").

\section{Understanding wars in order to promote peace}

8 Despite the limits in such categorizations, what this all bespeaks on Russell's part is a willingness, which he would never shed throughout the war, to understand "Why Nations Love War", to quote the title of an October 1914 article. He knows full well that lies and deceit and war propaganda do not suffice to produce the London crowds that, much to his amazement, paraded gaily on August $3^{\text {rd }} 1914$ in Trafalgar Square. He refers to these days in "The Rights of War" (Collected papers, p. 7)

"Those who saw the London crowds, during the nights leading up to the declaration of war, saw a whole population, hitherto peaceable and humane, precipitated in a few days down the steep slope to primitive barbarism..." that are conducive to war. Russell doesn't seem to have read Freud before 1917; he was introduced to Freud's writings ${ }^{17}$ by a few Bloomsbury acquaintances at Garsington, the Oxfordshire abode of his muse Ottoline Morrell. Also key in his appreciation of human impulses was his ephemeral albeit very intense friendship with D. H. Lawrence, which was instrumental in his elaboration of a series of talks entitled Principles of Social Reconstruction (1916), later to become his most important contribution to moral and political thinking.

11 True, the idea that there is lurking in man a wide range of brutal instincts, normally held in check in civilised life, was a somewhat pedestrian one, even back in 1914. What is less common is the brilliantly scathing political use that Russell makes of this, where more often than not he displays almost Swiftian talent :

This war is not being fought for any rational end: it is being fought because, at first, the nations wished to fight, and now they are angry and determined to win victory. Everything else is idle talk, artificial rationalizing of instinctive actions and passions. When two dogs fight in the street, no one supposes that anything but instinct prompts them, or that they are inspired by high and noble ends. But if they were capable of what is called thought, if they had been taught that Dog is a rational animal, we may be sure that a superstructure of belief would grow up in them during the combat. They fight really because something angers them in each other's smell. But if their fighting were accompanied by intellectual activity, the 
one would say he was fighting to promote the right kind of smell (Kultur), and the other to uphold the inherent canine right of running on the pavement (democracy). Yet this would not prevent the bystanders from seeing that their action was foolish, and that they ought to be parted as soon as possible. And what is true of dogs in the street is equally true of nations in the present war. ${ }^{18}$

However biologically rooted these impulses are, Russell is aware that they are not immutable; they largely depend on education and external circumstances, which politicians and the press manage to shape in their own interests. This is true as far as the fear of foreigners is concerned: if a man arms himself against his neighbour, the latter will be afraid and arm himself in turn, forcing the first man to arm himself more, etc. Russell was convinced that rather than guaranteeing peace and stability, armament generated fear and a feeling of insecurity, thus becoming the very root of a war which it was supposed originally to forestall. He believed that weak armies, or no armies at all, were preferable.

In order to prove his point he devised an extraordinary scenario, which was all the more provocative as it was published at a time when hatred climaxed, in August 1915, a few months after the sinking of the Lusitania and the first use of mustard gas at Ypres. In "War and Non-Resistance" (The Atlantic Monthly, Aug. 1915), he imagines a situation in which British people, having been thoroughly educated in the principles of passive resistance, opposed their civil and moral strength against the brutal force of potential German occupiers. There would be a few killings and many injustices, but far fewer than in the present conflict, since "there would be no glory to be won, not even enough to earn one iron cross. The Germans could not congratulate themselves upon their military prowess, or imagine that they were displaying the stern self-abnegation believed to be shown by willingness to die in the fight" ${ }^{19}$ After some time, having realized that they couldn't govern without the consent of the indigenous population, the Germans would have to leave and go home.

\section{A consequentialist attitude}

14 What Russell displays is a consequentialist attitude both towards war and towards pacifism, more in tune with the Weberian ethics of responsibility than with the Weberian ethics of conviction. In contrast with Tolstoy or G. M. Trevelyan, he does not consider actions to be inherently right or wrong. He believes that "if we judge conduct, as I think we ought, by its power of promoting what we consider a good life or a good society, we cannot expect such simplicity in our moral precepts, and we must expect all of them to be subject to exceptions". ${ }^{20}$ This is a classic debate that informs much of the history of pacifism in Britain. Historian Martin Ceadel makes an apt distinction between pacifists, "supporting the unconditional repudiation of war" ${ }^{21}$ and a broader group of loosely defined "pacificists", who are inclined to support the conditional use of force whilst international mechanisms empowered to prevent war are constituted.

Arguably, Russell also developed a consequentialist attitude towards pacifism itself. He grew more and more wary of peace for peace's sake, although he unabashedly clamoured for peace negotiations, as seen in two short July 1916 leaflets he produced for the NoConscription Fellowship : "Why Not Peace Negotiations ?" and "What Are We Fighting For ?" ${ }^{22} \mathrm{He}$ was irked by certain Quakers who promoted peace without really knowing how to do so, let alone what to do with peace once it was established. In private he described some meeting of the Union for Democratic Control as "eight fleas talking of building a pyramid"; in a June 1915 letter to Ottoline Morrell, he lamented the ineffectiveness of some activists by 
pointing out that "one might as well send a Quaker deputation to Etna and ask it not to erupt". ${ }^{23}$ Many of these statements were made in letters, since Russell, like others, depended a great deal on Quaker money to foster his cause. Likewise, despite his true admiration for its president E. D. Morel, whose imprisonment he denounced in "Six Months for Spreading Truth", Russell gradually distanced himself from the largest pacifist body in war-time Britain, the Union for Democratic Control, whose demands ${ }^{24}$ were, he felt, more appropriate to the post-war period than to war-time itself. By Spring 1916, he much preferred the radicalism and the immediate demands of the No-Conscription Fellowship, to whom we now turn.

\section{In the thick of it with conscientious objectors}

\section{Finding the heroes he was looking for}

As Russell was, in March 1916, still giving the lectures at London's Caxton Hall which would soon be published as Principles of Social Reconstruction, he became more familiar with the claims made by the No-Conscription Fellowship, and with a few of its leaders, whom he saw as heroes: Clifford Allen, Catherine Marshall, and Fenner Brockway. The N.C.F. had been created in November 1914 by radicals who believed -rightly, as it turned out- that conscription was an unavoidable next step in the British war drive. This clashed with the liberal ideals which were the very essence of Russell's politics. The British philosopher was far from alone in thinking this: Leonard Hobhouse had anticipated conscription after listening to Edward Grey's August $3^{\text {rd }} 1914$ speech. In a letter to his sister a few days later, he commented : "As to Liberalism it died last Monday". As for Russell, he woefully noted in a letter to Ottoline Morrell a few weeks before the conscription bill was introduced in Parliament : "conscription is so horrible it makes one forget everything else". ${ }^{25}$

Conscientious objectors were not prepared to fight because of a profound belief in the " sanctity of human life and the brotherhood of men", a phrase which was central to N.C.F propaganda. This refusal was either religiously, morally or politically motivated, and the Military Service Act introducing conscription allowed for certain exemptions, notably for Quakers. Lloyd George had himself guaranteed that those unwilling to fight for these reasons wouldn't be forced to, but that he would personally see to it that those who balked even at alternative, non-combatant service would be given a very hard time. ${ }^{26}$ Simultaneously, the Northcliffe press made sure to stigmatise these C.O.s as so many "shirkers". In fact, no sooner had the expression "conscientious objectors" entered the English language than it became a term of abuse, as Arthur Marwick notes in his classic study The Deluge. ${ }^{27}$

Bertrand Russell and Catherine Marshall spent the whole of 1917 running the N.C.F, since both Clifford Allen and Fenner Brockway were in prison. Russell wrote 53 editorials for The Tribunal, and ran the organisation flawlessly: according to historian Charles Kennedy, "Russell's association with the N.C.F unquestionably cost him a good deal more than he had bargained for, but no member contributed more [to] the indomitable spirit and indeed the very survival of the organization". ${ }^{28} \mathrm{He}$ displayed a real talent at mediating between the "absolutists" (those who refused either non-combatant service or civilian service) and the "alternativists" (those who on the contrary were ready to accept such tasks). Theoretically, he sided with the absolutists, for whom he had great admiration, and wished time and again he were eligible for service, since there was clearly a streak of the 
martyr in him. Yet when it became clear that absolutists made up but a small minority of conscientious objectors, he chose to remain both pragmatic and faithful to his liberal ideals: "if you disbelieve in alternative service, stand out against it, no matter what the Government may do to you; if you believe in it, take it, no matter what the absolutists may say to you". ${ }^{29}$

As soon as Russell finished his lectures at Caxton Hall he devoted his whole time and energy to the conscientious objectors. He discovered two talents on which the NCF drew heavily: one as an orator, the other one as a polemicist. He lambasted the government's schemes to find solutions to the question of conscientious objectors, and expressed his distaste of tribunal appeals. These were often made up of rustic civilians, none of whom had had "anything approaching a good education", and who were often hell-bent on meting out hard labour sentences to those they saw as a bunch of shirkers: "A tribunal to judge conscience must be at all times grotesque, but surely the Cambridge Appeal Tribunal reaches the limits of absurdity" ("Folly, doctor-like, controlling skill"). ${ }^{30} \mathrm{He}$ was vitriolic about the Pelham Committee, whose function it was to find alternative service for certain objectors: ${ }_{31}$ "The man who has been teaching Physics must be made to hoe potatoes; the man who has been hoeing potatoes must be set to teach Physics. Potatoes and Physics both cease to be produced by this arrangement; but both men suffer, so all is well". ${ }^{32}$ More importantly, he published "The Everett Leaflet", to defend an absolutist teacher from St Helens, a document which was circulated free on April $19^{\text {th }}$ and $20^{\text {th }}$; between 250000 and half a million copies were sent out. As of that date, when Russell admitted to having been the author of this text to The Times (“Adsum Que Feci", 17. 05. 1916), the Home Office became determined to muzzle him, whilst avoiding making a martyr of him. This was one of the reasons why, despite his fame both before and after the war, Russell had to publish several leaflets anonymously, or under a false name; the real authorship of certain key texts in World War One pacifism was only revealed years later, often by some of Russell's comrades, such as Fenner Brockway. This was the case for instance of I Appeal Unto Caesar (summer 1917), officially authored by Margaret Hobhouse, and which sold more than 17000 copies in a very short time.

\section{The unsent letter}

The paradox in Russell's total involvement with the N.C.F is that, whilst he devoted nearly all his time and energy to them (especially in 1917), he became fairly rapidly dissatisfied with the way their immediate objectives blinded them to a full appreciation of the bigger picture, i. e. the fundamental evil of the capitalist system, now made all the more glaring by the Russian events. In a way, hearing about the Russian revolution in March 1917 came in the nick of time, just like hearing about the Conscientious Objectors one year before. In the first days of the war, he had made it clear that liberalism as he saw it was not served by the Liberal party, which had unashamedly betrayed a glorious political heritage in Britain, to which his own family belonged. ${ }^{33}$ What followed was then quite logical: he became keenly interested in socialism, promoted the abolition of the capitalist system in The World As It Can Be Made, and joined the Independent Labour Party on June $10^{\text {th }} 1917$, one week after the Leeds Convention, where radicals of different hues had planned the establishment of British Soviets.

21 The Collected Papers (Vol 13) includes a quite extraordinary document: a letter of resignation from the N.C.F. which Russell wrote on May $18^{\text {th }} 1917$, and which he marked 
"Private and Confidential". It turned out that he never actually sent this letter, that the paper was all crumpled because he kept it in his pocket for a while, probably in case some meeting turned very sour. Be that as it may, the contents of the document highlights certain of his concerns about his place within the N.C.F. The fact that he never revealed anything about the document probably boils down to his sincere admiration for the likes of Allen, Marshall and Brockway.

\section{Pacifism, revolution and violence}

\section{The Russian revolution}

The writing of this unsent resignation letter was undoubtedly prompted by the encouraging news from Russia, where the Petrograd Soviet was demanding immediate peace without annexation or indemnity, and by the large meeting at the Albert Hall in London, organized on March 31st by socialist George Lansbury. This was a real success, and Russell was there in the enthusiastic crowd to listen to speeches by radical tradeunion leaders, Robert Smillie and Robert Williams among others.

In the unsent letter, Russell tried to gauge the possibilities of a revolutionary spill-over in his country: "I do not myself believe that there is any chance of a revolution in this country, but there is reason to suppose that the Government thinks otherwise, and that fear of revolution will be a powerful motive with the authorities in leading them to desire an early end to the war". ${ }^{34}$ This type of (unpublished) statement helps us understand how Russell was pushing for urgent and radical social reforms at a time of great industrial unrest, especially in South Wales (where he spoke 35 times in the summer of 1916) and Western Scotland, (where Robert Smillie had to read his "The World As it Can Be Made" lecture, Russell being banned from the Glasgow area). At a time when the N.C.F was becoming more and more embroiled in internecine feuds over absolutists and alternativists, Russell realized that the urgency of the social situation, spurred by the international context and the growing demands for peace all tended to make the N.C.F a somewhat inadequate tool. This was all the more so as many N.C.F. activists -especially Quaker absolutists- were unwilling to take part in the socialist movement. What is more, the larger number of those who were unwilling to serve would soon be drawn from workers potentially "combed out" from hitherto strategic industries, such as miners afraid to be sent to the front, at a time (Spring 1917) when soldiers were lacking more than ever.

\section{The urgency of the broader picture}

In July 1917, Russsell published three consecutive texts for The Tribunal, the N.C.F newspaper. These all deal with the connections between pacifism and revolution: "Pacifism and Economic Revolution", "A Pacifist Revolution?", "Pacifism and Revolution", and articulate a clearer view of his consequentialist approach to pacifism. These, to be sure, make up a rhetorical trilogy to convert pacifists to the revolutionary movement. Fundamentally, Russell argues that the genuine pacifist neither seeks peace for its own sake (or order and security per se), nor for himself (his individual tranquillity or comfort). He strives for peace in order that all human lives may flourish freely, because what motivates a pacifist is the brotherhood of men. That brotherhood naturally makes the 
pacifist keenly aware of all forms of oppression, be they national, economic, political, religious, etc. This is why the pacifist should struggle to abolish capitalist and State domination, in order to wholly rebuild society on a new basis.

In the unsent resignation letter, Russell had already made a point on violence :

I have always held, and publicly stated, that the use of force in revolutions is not necessarily to be condemned. Until lately, this was merely an academic reservation, without relevance to the actual situation. Now, however, it has become a pressing practical consideration. A certain amount of bloodshed occurred during the Russian Revolution, probably unnecessarily. If it was unnecessary, I can of course condemn it; but if the revolution could not be accomplished without it, I cannot condemn it. 35

26 In these three articles, he elaborated in greater detail on the notion of violence. It is wrong according to him to necessarily connect revolution with violence. Revolution strives to build a world without violence, despite the frequent resort to it in the early stages of revolution. Any revolution spurred by hatred and a thirst for revenge will only end up with a new form of domination, a mere change of rulers. He painstakingly tries to show that the source of the revolutionary spirit and the source of pacifism are ultimately analogous. The risk of violence exists but it is worth taking that chance. Also, the risk has been greater in a country like Russia, led by a despotic family since times immemorial. He argues time and again that in Britain, "The sort of movement which achieves its ends through violence and civil war is extremely improbable in a country where the Government has acquired the habit of being responsive to public opinion", ${ }^{36}$ a typically liberal view which was expressed later by Orwell, who generalized on the notion that "The English are not good haters" ${ }^{\prime 37}$. Hence the interiorized need by the Powers that Be to mould, even to fabricate, public opinion: this fabrication might come from newspapers themselves ("Lord Northcliffe's Triumph", The Labour Leader, 27. 05. 1915; "The Times on Revolution", The Pioneer, 06. 10. 1917), from the education system through its school books ("The Rights of the War", The Nation, 15. 08. 1914) or from the Church of England prelates ("A Valuable Suggestion to the Bishop of Exeter", The Tribunal, 11. 10. 1917). Needless to say such articles would wield a deep influence on radical thinkers like, again, George Orwell and Noam Chomsky.

\section{Bitter epiphany at Southgate}

On July $28^{\text {th }} 1917$, six weeks after the encouraging Leeds Convention, Russell attended a (normally) secret meeting at Southgate Brotherhood Church, in what today would be Hackney. The pacifist crowd gathered there to discuss whether the creation of a London Soviet was feasible. It seems that Russell himself was ready to accept the burden of leading this Soviet, which never materialized. The information about the meeting had just been leaked to Basil Thompson, chief of the Special Branch ${ }^{38}$ who wrote in his diary on July $27^{\text {th: }}$ "They [the pacifists] will have a rude awakening tomorrow, as I have arranged with the Daily Express to publish the place of their meeting, and a strong opposition may be expected. The same may be expected at Swansea next week". ${ }^{39}$ Russell was right to point to a tightlyknit coalition between the various agents of the State. Yet he was wrong to believe that the State itself was afraid of the revolutionary potential in Britain: by the summer of 1917, the government would ruthlessly disrupt the connections made between the pacifist and the revolutionary movements, arresting the leaders, raiding places of sedition, destroying printing facilities. 
28 At Southgate Brotherhood Church, the angry crowd which disrupted the meeting was made up of two distinct groups : drunken louts (including many women) there to avenge themselves against "German spies" or to just have fun, and young soldiers who had been manipulated into believing that the pacifists were traitors and shirkers that should be taught a lesson. Russell recalls in his autobiography how he was saved by a pacifist woman, the crowd that singled him out not daring to harass a female. ${ }^{40}$ When he came home after that harrowing experience, he wrote to Ottoline Morrell: "I realized vividly how ghastly the spirit of violence is, and how utterly I repudiate it, on whatever side it may be. The mob is a terrible thing when it wants blood. The young soldiers were pathetic, thinking we were their enemies. They all believed we were in the pay of the Kaiser" ${ }^{\prime 1}$. The theoretical legitimation of violence he had given under certain circumstances in his resignation letter, and which had become a pressing pragmatic matter, crumbled in a few minutes with the actual witnessing of violence.

This traumatic event he also recalls in a moving text, "Crucify Him! Crucify Him!", ${ }^{42}$ which, quite extraordinarily, strikes an optimistic chord of sorts. He recalls the way much of the pacifist crowd inside the Church remained completely still for a while, generating a sense of unease among the aggressors. He then contemplates how this behaviour could be transformed, to the pacifists' advantage, into wholesale passive resistance: some people would be wounded, but ultimately the mob would realize how brave these supposed shirkers were, and how futile violence is when it is not being resisted.

After Southgate, Russell had a two-week break in Shropshire with his mistress Constance Malleson. He would continue his work as an editorialist for The Tribunal, and one of the articles he published in 1918 would cause his imprisonment. In "The German Peace Offer" (03. 01. 1918), he refers to the way an American garrison could well be used after the war to disrupt strikes in England and France and assist strike-breakers, a fairly common practice in the U.S. He was sentenced to six months in prison for making a "statement likely to prejudice His Majesty's relations with a foreign power". There was a double irony here: first, he had already made a similar statement in "Imperialist Anxieties" (The Tribunal, 30. 08. 1917) which hadn't caused such a stir. Secondly, he was sent to prison at a time when he was seriously thinking about going back to philosophy. He finally served four and a half months, as a second division prisoner, i. e. in fairly good conditions which made it possible for him to read, write, and eat a bit of chocolate. The irredeemable damage the likes of Allen and Morel had suffered as first division prisoners would fortunately be spared to Russell. To have such a renowned scholar serve a prison sentence can only have been decided at the very highest level: now that most N.C.F and U.D.C leaders were jailed or too weak to be a threat, it was time for "one of the most mischievous cranks" in the country to be silenced. The decision not to class Russell as a second division prisoner (where conditions were very harsh) but as a first division prisoner was explained on the grounds that "it would be a great loss to the country if Mr Russell, a man of great distinction, were confined in such a form that his abilities would not have full scope". ${ }^{43}$ Apparently, this decision too was taken at a very high level, possibly by Balfour, who had been trained as a philosopher.

\section{Conclusion: pacifism and the solitary condition}

31 One of the editors of the Collected Papers argues that "Russell wrote and talked so much to people who shared his pacifist values that he often failed to grasp just how small a 
minority of his countrymen agreed with these ideas" ${ }^{44}$ The night the war was declared, Russell felt a pang of estrangement when he witnessed the joy of the London crowds welcoming the conflict with Germany. More than four years later, he recalled the time immediately after the armistice: "The crowd was frivolous still, and had learned nothing during the period of horror, except to snatch at pleasure more recklessly than before. I felt strangely solitary amid the rejoicings, like a ghost dropped by accident from some other planet". ${ }^{45}$ To be sure, one of the reasons for such gloom was that, ever since the first days of the war, Russell had warned against the perils in any humiliating peace treaty against Germany. Like Keynes or Gandhi, but as early as 1914, Russell stressed the need to draw a historical lesson from the spirit of revanchisme which the French had nourished after $1870 .{ }^{46}$ The disappointment with the treaty of Versailles, the failure of the Wilsonian internationalist ideal and his own disillusionment with both Russia -that he visited in 1919- and the United States, meant that one of the key intellectuals of the $20^{\text {th }}$ century remained in the background for much of the 1920s and 1930s.

Martin Ceadel explains the geographical justification for his title Semi-Detached Idealists by referring to the way British pacifists were "close enough to the continent to fear being drawn into any major war which breaks out there, yet distant enough not to be permanently anxious about national security". ${ }^{47}$ More than anybody else, Russell embodied that type of pacifist: drawn to admire Germany because of his philosophical training, tending to despise Tsarist Russia through his liberalism and his friendship with Ludwig Wittgenstein and Joseph Conrad, Russell was also a pacifist because his own positive and negative prejudices make him suspicious of a war where Britain allied itself with Russia against Germany. Pacifism is very often bound up with internationalism, and it is also in this way that Russell's internationalism needs to be appraised.

In order to articulate the best definition of pacifism, Russell was inspired by personal, national as well as international events, like many of his comrades. But unlike them, he combined a dogged spirit of activism with a vast knowledge in different fields: moral philosophy, history, economics, politics, and to a lesser extent psychology, which helped him fathom the "Prussian lurking" in the warlike instincts of the British. Frequently arguing that he had more in common with a German pacifist than with a British warmonger, Russell defended a pacifism which drew all these elements together in a complex skein, and made the notion of peace for peace's sake a somewhat naive irrelevance.

\section{BIBLIOGRAPHY}

CEADEL, Martin, Semi-Detached Idealists: the British Peace Movement and International Relations, London \& New York : Oxford University Press, 2000, 477 p.

COLLINI, Stefan, Absent Minds, Intellectuals in Britain, London \& New York : Oxford University Press, 2006, $544 \mathrm{p}$. 
ESTEVES, Olivier, «L'intellectuel et la horde : Bertrand Russell, témoin de l'émeute anti-pacifiste de Southgate Brotherhood Church (28.07.1917) ", in Recherches Britanniques (www.recherchesbritanniques.com), $\mathrm{n}^{\circ} 2,2014$ (forthcoming).

ESTEVES, Olivier, «L'anticolonialisme de George Orwell et Bertrand Russell » in Revue Agone ${ }^{\circ} 45$, 2011, pp. 97-119.

IRONSIDE, Philip, The Social and Political Thought of Bertrand Russell, The development of an aristocratic liberalism, London \& New York : Oxford University Press, 1996, 280 p.

KENNEDY, Thomas, The Hound of Conscience, A History of the No-Conscription Fellowship, 1914-1919, Fayetteville (Ark.) : University of Arkansas Press, 1981, 322 p.

LUKES, Steven, Liberals and Cannibals : The Implications of Diversity, London : Verso, 2003, 184 p.

MARWICK, Arthur, The Deluge: British Society and the First World War, Basingstoke : Macmillan, 1991 [1965], 376 p.

MONK, Ray, Bertrand Russell, The Spirit of Solitude 1872-1921, New York : The Free Press, 1996, 695 p. ORWELL, George, “The English People”, in Orwell's England, London : Penguin 2001, 496 p.

RUSSELL Bertrand, Le Pacifisme et la révolution, écrits politiques (1914-1918), Marseille : Agone, 2014, $355 \mathrm{p}$.

RUSSELL, Bertrand, The Collected Papers of B. R., Vol. 13, Prophecy and Dissent, London : Routledge, $1988,680 \mathrm{p}$.

RUSSELL, Bertrand, The Collected Papers of B. R, Vol. 14, Pacifism and Revolution, London : Routledge, $1995,630 \mathrm{p}$.

RUSSELL, Bertrand, The Collected Papers of B. R, Vol. 15, Uncertain Paths To Freedom, Russia and China, 1919-1922, London : Routledge, 2000, 800 p.

RUSSELL, Bertrand, Autobiography of B. R., The Middle Years, Vol. II, London : Allen \& Unwin, 1968, $255 \mathrm{p}$.

VELLACOTT, Jo, Bertrand Russell and the Pacifists in the First World War, New York : St Martin's Press, 1980, $326 \mathrm{p}$.

\section{NOTES}

1. Principia Mathematica (1910-1913), with Alfred North Whitehead, published in three volumes.

2. As of September $1^{\text {st }} 1916$, he was banned from going to "coastal areas" (loosely defined as $1 / 3$ of the British territory) since he was deemed a security risk under the Defence of The Realm Act. That treatment was usually meted out to alleged German spies.

3. Confidential Report by Lord Newton, July $7^{\text {th }} 1916$, quoted in VELLACOTT, Jo, Bertrand Russell and the Pacifists in the First World War, New York : St Martin's Press, 1980, p. 79.

4. I am using the word in a fairly loose sense, a word which Russell would apply to himself as well as criticize. On his use of the word, and his position as a British intellectual, see Stefan COLLINI, Absent Minds, Intellectuals in Britain, London \& New York : Oxford University Press, 2006, p. 28, pp. 120-3.

5. Bertrand RUSSELL, Le Pacifisme et la révolution, écrits politiques (1914-1918), Marseille: Agone, 2014, edited by Olivier Esteves and Jean-Jacques Rosat, translated by Olivier Esteves and Claire Habart. 
6. Bertrand RUSSELL, The Collected Papers of B. R., Vol. 13, Prophecy and Dissent, London : Routledge, 1988, p. 67 (later referred to as CPBR 13).

7. American anthropologist William Graham Sumner had coined the word "ethnocentrism" in his 1906 essay Folkways. On the background to this, see Steven LUKES, Liberals and Cannibals: The Implications of Diversity, London : Verso, 2003, p. 12-3.

8. For a more comprehensive critique of this, see Olivier Esteves, «l'anti-colonialisme de George Orwell et Bertrand Russell », Revue Agone, n45 (2011), p. 105-6.

9. CPBR 13, p. 67.

10. This expression is expressed with a few nuances in Ibid., pp. 7, 164, 177, 178, 329-338, 416 ; in The Collected Papers of B. R. : Vol. 14, Pacifism and Revolution 1916-1918 (later referred to as CPBR 14), London : Routledge, 1995, pp. 21, 22, 204, 232, 259, 270, 399 ; The Collected Papers of B. R., Vol. 15, Uncertain Paths to Freedom : Russia and China, 1919-1922, London : Routledge, 2000, p. 150.

11. Ibid., p. 153.

12. This was bizarrely published under the title Political Ideals, which itself is the title to the first lecture.

13. CPBR 13, p. 69.

14. Ibid., p. 70.

15. Ibid., p. 72.

16. Ibid., p. 166.

17. See Philip IRONSIDE, The Social and Political Thought of Bertrand Russell, The Development of an Aristocratic Liberalism, Cambridge University Press, 1996, p. 111-112.

18. "On Justice in War-Time, An Appeal to the Intellectuals of Europe", The International Review (Aug. 1915), in CPBR 13, p. 178.

19. Ibid., p. 161.

20. Ibid., p. 158

21. Martin CEADEL, Semi-Detached Idealists: the British Peace Movement and International Relations, London \& New York : Oxford University Press, 2000, pp. 1-2.

22. CPBR 13, pp. 418-420.

23. See respectively, Jo VELLACOTT, op.cit., p. 12, p. 23.

24. These were : a democratisation of foreign policy, the end to secret diplomacy (which Russell time and again advocated), and the introduction of some international council of nations.

25. For both quotes, see CPBR 13, p. liii.

26. See Arthur MARWICK, The Deluge, British Society in the First World War, Basingstoke : Macmillan, 1991 [1965], p. 120.

27. Ibid., p. 121.

28. Thomas KENNEDY, The Hound of Conscience, A History of the No-Conscription Fellowship, 1914-1919, Fayetteville (Ark.) : University of Arkansas Press, 1981, p. 109.

29. The Tribunal, 12. 10. 1916 quoted in Ibid., p. 165.

30. This text, taking its title from Shakespeare's $66^{\text {th }}$ sonnet, was finally unpublished. It was written in May 1916. See Ibid., p. 360.

31. This largely ineffective body was set up in March 1916. More specifically, its mission was Civilian service for COs in work of national importance. The Pelham Committee dealt only with the small number (it reviewed 4000 cases) whose exemption was conditional on being employed in such work.

32. B. R., "An open letter to some would-be friends of the conscientious objector" (probably June 26th 1916), in Russell, $n^{\circ} 19,1999-2000$, p. 179. This text, among others, was found out too late to be included in the Collected Papers.

33. His grandfather was Lord John Russell, twice Prime Minister (1846-1852 ; 1865-1866) ; his godfather was John Stuart Mill.

34. CPBR 14, p. 163.

Revue Française de Civilisation Britannique, XX-1 | 2015 
35. CPBR 14, p. 163.

36. CPBR 14, p. 196.

37. George ORWELL, “The English People”, in Orwell's England, London : Penguin 2001, p. 303.

38. This was a 114-man unit set up in 1914 to carry out investigations to protect the State from perceived menaces of subversion.

39. Quoted in Olivier ESTEVES, «L'intellectuel et la horde : Bertrand Russell, témoin de l'émeute anti-pacifiste de Southgate Brotherhood Church (28.07.1917)», in Recherches Britanniques ( www.recherches-britanniques.com), $\mathrm{n}^{\circ} 2,2014$ (forthcoming).

40. B .R., Autobiography of B. R., The Middle Years, Vol. II, London : Allen \& Unwin, 1968, p. 112.

41. Quoted in Jo VELLACOTT, op.cit., p. 170.

42. CPBR 14, p. 285-6.

43. Ibid., p. 396.

44. Ibid. : $\mathrm{xx}$

45. Philip IRONSIDE, op.cit., p. 143

46. He made this clear a few times, especially in "Will This War End War?" (The Labour Leader, 10. 09. 1914), an overt critique of H. G. Wells's naive slogan on "the war to end all wars", see CPGB 13, p. 12-15.

47. Quoted in op.cit., p. 5-6.

\section{ABSTRACTS}

Bertrand Russell (1872-1970), one of the towering intellectuals of the 20th century, was an indefatigable pacifist throughout the Great War. But his pacifism was not unreserved, depending as it did on his consequentialist attitude towards war and towards pacifism. This chapter gives a description and analysis of the key stages in Russell's political itinerary from 1914 to 1918 : on the declaration of war, on the introduction of conscription, at the time of the Russian revolutions and when there appeared the prospect of profound social and political changes in Britain.

Bertrand Russell (1872-1970), un des plus grands intellectuels du 20ème siècle, fut un infatigable pacifiste pendant la Première Guerre Mondiale. Mais ce pacifisme n'était pas sans condition, chez un philosophe libéral à l'approche conséquentialiste, tant par rapport à la guerre elle-même que par rapport au pacifisme. Ce chapitre offre une description et une analyse des principaux épisodes de l'itinéraire intellectuel de Russell entre 1914 et 1918 : entrée en guerre, introduction de la conscription, révolutions russes et possibilité de changements politiques et sociaux radicaux en Grande-Bretagne.

\section{INDEX}

Mots-clés: Russell Bertrand, intellectuel, pacifisme, objection de conscience, conscription, libéralisme politique, conséquentialisme, Confrérie contre la conscription, Union pour un Contrôle Démocratique

Keywords: Russell Bertrand, intellectual, pacifism, conscientious objection, conscription, political liberalism, consequentialism, No-Conscription Fellowship, Union for Democratic Control 
AUTHOR

OLIVIER ESTEVES

Université Lille 3 